\title{
POTENTIAL OF 77,78 MW RED DIODE LASER FOR PHOTODYNAMIC
}

\author{
Basitha Febrinda Hidayatulail, Irfan Mujahidin
}

\begin{abstract}
A laser is a light source that uses for any kinds of medical application. Diode Laser is one laser type using in the medical application such as Photodynamic Therapy and Photodynamic inactivation. Photodynamic Therapy is one of non-invasive therapy using for many therapies such as antimicrobial therapy, rejuvenating skin therapy, anti-aging skin therapy, etc. This therapy is using a light source with specific characteristics of wavelength in some case are using Light-sensitive molecules. This research aims to determine the potential of the diode laser for photodynamic therapy instrument. Diode Laser with wavelength value $660 \mathrm{~nm}$ is Red Laser Diode that has main power output 79,4 $\mathrm{mW}$. The application was using $1 \mathrm{~cm}$ clearance with the 30s of time exposure. The result showed that for Diode Laser $(\lambda) 660 \mathrm{~nm}$ using $7,8 \times 10^{-2} \mathrm{~W}$ input power produce $77,78 \mathrm{~mW}$ output power; has operational temperature $53.56^{\circ} \mathrm{C}$ and light beam $4.2 \mathrm{~mm}^{2}$.
\end{abstract}

Index Terms-Diode Laser, Light Instrumen, Photodynamic, Photoinactivation.

\section{INTRODUCTION}

L aser systems can be classified as continuous wave (CW) lasers and pulsed lasers. Whereas most gas lasers and to some extent also solid-state lasers belong to the first group, the family of pulsed lasers mainly includes solid-state lasers, excimer lasers, and certain dye lasers[1][2]. Light is one of the important components in photodynamic therapy because the energy of photons produced by light serves to activate the photosensitizer molecule so that a photophysical process occurs as the beginning of a photodynamic mechanism. Light used in photodynamic therapy must be harmless and is visible or near IR light[3][4].

Beginning in the late 1960s, lasers were also introduced to other medical disciplines. And today, various types of laser procedures are carried out throughout the world. Mostly used minimally invasive surgery (MIS), the new term describes a contactless and bloodless surgical procedure. Both of these characteristics support the use of lasers to become universal scalpels and treatment assistance. Diode Laser is one laser type using in medical application such as Photodynamic Therapy and Photodynamic inactivation.

Basitha Febrinda Hidayatulail, Electrical Engineering Departemen of Universitas Merdeka Malang, Malang, Indonesia (email basitha@unmer.ac.id)

Irfan Mujahidin, Electrical Engineering Departement of Universitas Merdeka Malang, Malang, Indonesia (email irfan.mujahidin@unmer.ac.id)
Photodynamic Therapy is one of non-invasive therapy using for many therapy such as anti microbial therapy, rejuvenating skin therapy, anti aging skin therapy, etc. This therapy is using light source with specific characteristics of wavelength in some case are using Light-sensitive molecules. This research aims to determine the potential of the diode laser for potodynamic therapy instrument[5][6].

\section{MATERIAL AND METHOD}

\section{A. 660nm Diode Laser}

Diode Laser is used as Light source. The specification of Laser wavelength $(\lambda)$ value $660 \mathrm{~nm}$, power $200 \mathrm{~mW}$.

\section{B. Spectrometer}

Spectrometer is used to analyse diode laser spectrum and to calibrate the diode laser.

\section{Thermometer}

Thermometer is used to measured operation themperature of Diode laser.

\section{Research Method}

The method used to measured the diode laser stability is using a laser spectrum analyzer. Measurement of the operational time and output power to determine the stability of laser. Fig. 1 is a research diagram measuring the stability of a laser diode[7][8]

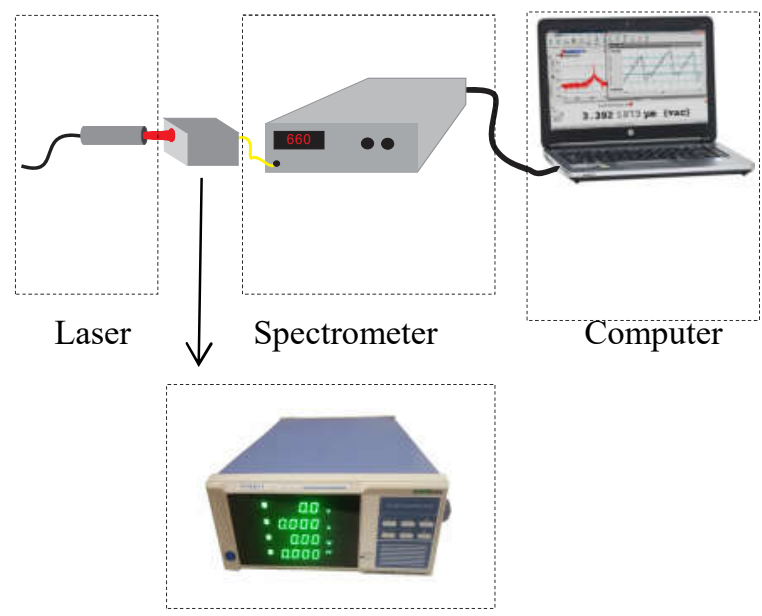

Powermeter

Figure. 1. Research Scheme of Diode Laser Caracterization

Figure. 1 shows that the diode laser as light source and then analyzed using a spectrum analyzer and the data 
received was displayed on the computer. After testing the stability and operating power of the laser then the measurement continued at the power measurement using digital powermeter, measurement of operation temperature using digital thermometer and the Light beam[9][10].

\section{RESULT AND ANALYSIS}

\section{A. Output Power of Diode Laser}

The characterization of laser stability was carried out using Laser Spectrum Analyzer. Analysis of diode laser operation carried out in the few stages, first stage is a measuring the wavelength by the output power that shown in Fig. 2. This data shows that the laser diode works in $645 \mathrm{~nm}-665 \mathrm{~nm}$ wavelength range and has the highest value at $660 \mathrm{~nm}$ wavelength with an output power value $77.78 \mathrm{~mW}$

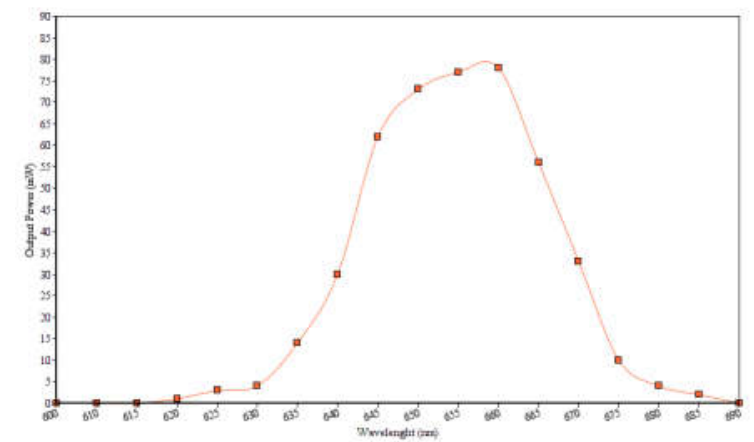

Figure. 2. Characterization of Diode Laser

In figure. 3 showing the measurement results of Input to Output Power.
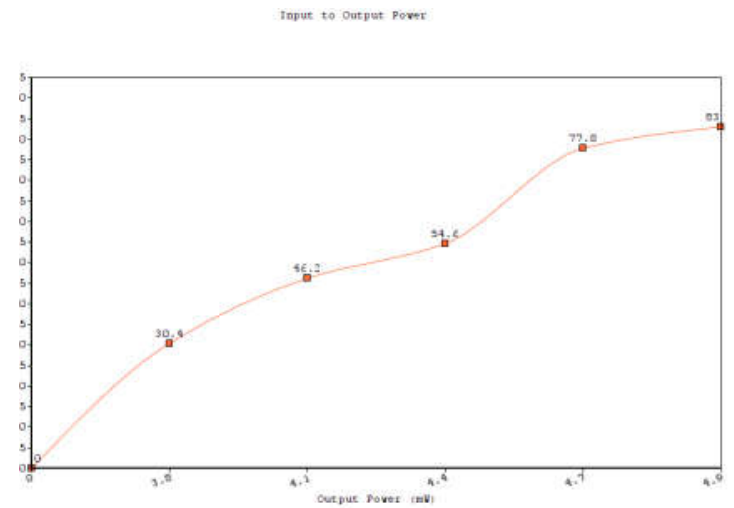

Figure. 3. Output Power of Input Power to Output Power

To control the input value of the laser, the Control Unit is used so that it adjusts the input voltage from the laser and know the difference in output values. At Fig. 3 shows that the input value increases then the output value will increase too. In this situation the output value of $77.8 \mathrm{~mW}$ is chosen to see the potential of that value[11].

In figure. 4 showing the measurement results of stability operation.

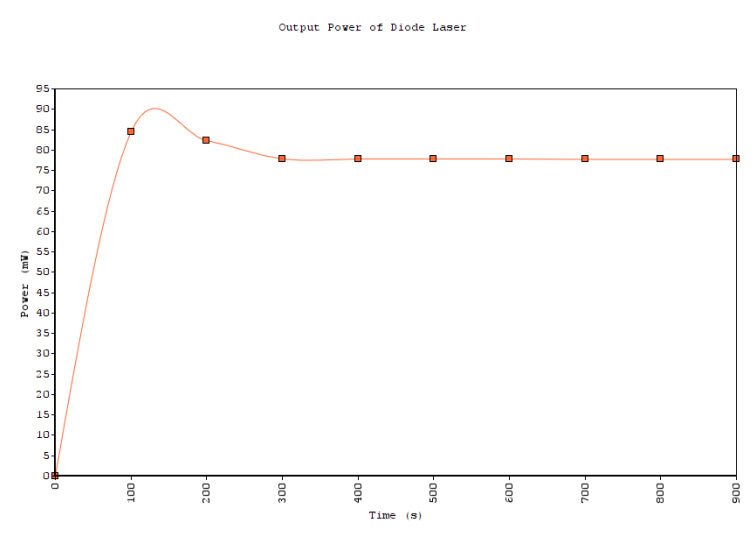

Figure. 4. Output Power of stability operation

In the graph shows that the operation of laser diode cannot directly reach a stable value but must reach a certain time. The beginning of the diode laser operation the value dramatically rose at $84.8 \mathrm{~mW}$ and then gradually dropped at the 245 seconds of operation showed a stable value at $77.8 \mathrm{~mW}$ untill 900 seconds[12][13].

\section{B. Operation Temperature of Diode Laser}

The diode laser has a working temperature depending on the time of irradiation. This happens due to the photothermal reaction from the process of irradiating laser light with a certain power. Characterization of laser working temperature is done by measuring the laser irradiation time operating and measured using a digital thermometer. The table below shows the results of the working temperature of the diode laser[14].

Table. 1 Diode Laser Operational Temperature

\begin{tabular}{cc}
\hline Time (s) & $\begin{array}{c}\text { Temperature } \\
\left({ }^{\circ} \mathbf{C}\right)\end{array}$ \\
\hline $\mathbf{0}$ & 26.6 \\
$\mathbf{5}$ & 39.6 \\
$\mathbf{1 0}$ & 46.4 \\
\hline $\mathbf{1 5}$ & 49 \\
\hline $\mathbf{2 0}$ & 48.8 \\
\hline $\mathbf{2 5}$ & 50.4 \\
\hline $\mathbf{3 0}$ & 50.9 \\
\hline $\mathbf{3 5}$ & 51.1 \\
\hline $\mathbf{4 0}$ & 51.2 \\
\hline $\mathbf{4 5}$ & 51.4 \\
\hline $\mathbf{5 0}$ & 51.45 \\
\hline $\mathbf{5 5}$ & 51.6 \\
\hline $\mathbf{6 0}$ & 51.6 \\
\hline
\end{tabular}

The results of the working temperature graph of diode laser are shown in Figure. 4. 


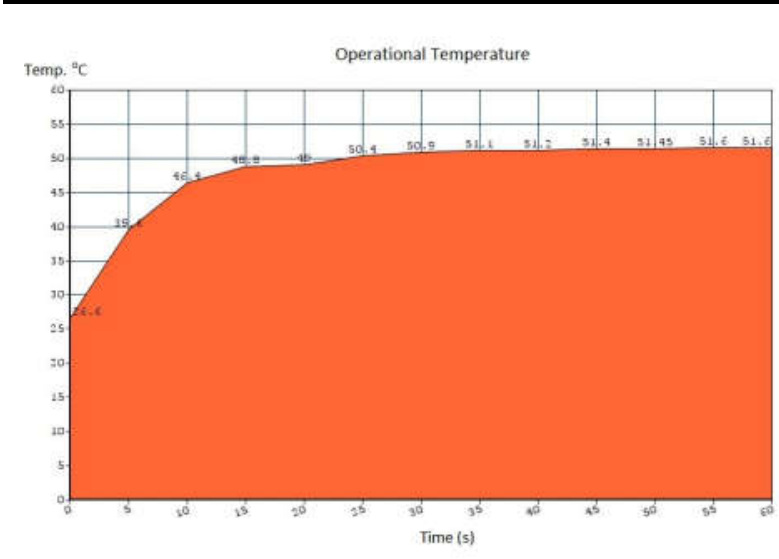

Figure. 5. Operational Temperature

It can be seen that the working temperature of the laser diode is directly linear with the time of laser irradiation. When the laser irradiation has longer time operational, the operating temperature generally rise.

\section{Light Beam of Diode Laser}

The light beam of Diode Laser will change its beam each distance traveled. Light beam diode lasers will tend to be elliptical with various divergence angles.

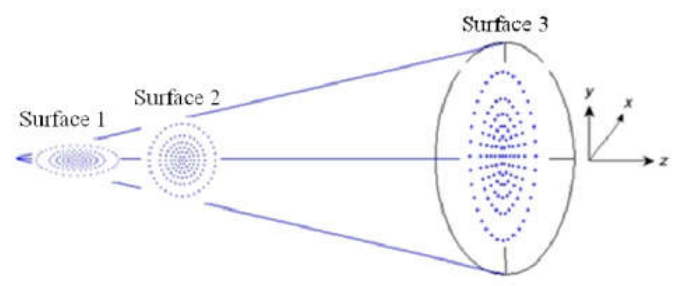

Figure. 6. The light beam of Diode Laser

Shown in figure 6 , the first diode laser beam emission (emission strip) will be in the form of an ellipse with the largest diameter on the $\mathrm{x}$-axis. Furthermore, at a distance (z-axis) of several microns, the diode laser emission strip turns into a circular shape. Then the diode laser beam is again in the form of an ellipse with the largest diameter on the y-axis after a long distance.

Table 2 showing the result of light beam by the distance of laser irradiation.

Table 2. Light Beam Area

\begin{tabular}{cc}
\hline Distance (cm) & Light Beam $\left.\mathbf{( m m}^{\mathbf{2}}\right)$ \\
\hline $\mathbf{0}$ & 0 \\
\hline $\mathbf{1}$ & 4.2 \\
\hline $\mathbf{2}$ & 4.8 \\
\hline $\mathbf{3}$ & 5.8 \\
\hline $\mathbf{4}$ & 6.4 \\
\hline $\mathbf{5}$ & 6.9 \\
\hline
\end{tabular}

\section{Characterization Result}

Based on few testing stage the results shown in the table. 3.

Table 3. Laser Characterization Result

\begin{tabular}{cc}
\hline Testing Stage & Result \\
\hline Wavelenght $(\boldsymbol{\lambda})$ & $660 \mathrm{~nm}$ \\
\hline Input & $4.7 \mathrm{~V}$ \\
\hline Output Power & $77.8 \mathrm{~mW}$ \\
\hline
\end{tabular}

\begin{tabular}{cc}
\hline Stability Time & $243 \mathrm{~s}$ \\
\hline Temperature & $50.9^{\circ} \mathrm{C} / 30 \mathrm{~s}$ \\
\hline Light Beam & $4.2 \mathrm{~mm}^{2} / \mathrm{cm}$ \\
\hline
\end{tabular}

The first testing stage is to determine the stability of diode laser, efficiency wavelength laser operation and to know the output power that most suitable with photodynamic. The result of the first stage is shown in table 3 number 1-4.

The second testing stage is to regulate the temperature of diode laser operation who suitable with the photodynamic process and do not causing damage to the treated tissue, it present in table 3 number 5 .

The final stage of test is to reveal the light beam area to calculate the cross-sectional area treated, it showed in the last of table 3 .

\section{CONCLUSION}

The results show that the potential of the laser diode for photodynamics can be done at a wavelength $(\lambda)$ of $660 \mathrm{~nm}$ because the absorption of red light to the tissue is deeper than the blue light, with an output power value of $77.8 \mathrm{~mW}$ the permitted operation temperature is less than $60{ }^{\circ} \mathrm{C}$ so it not cause the tissue infection. The maximum irradiation time is $30 \mathrm{~s}$ to prevent an increase in the operation temperature of the laser. The light beam wide is $4.2 \mathrm{~mm}^{2}$.

\section{ACKNOWLEDGMENT}

This research was partially supported by Institute of Tropical Deseas. We thank our colleagues from Airlangga University who provided insight and expertise that greatly assisted the research, although they may not agree with all of the interpretations of this paper.

\section{REFERENCES}

[1] D. Bäuerle, Laser Processing and Chemistry. 2011.

[2] B. Febrinda Hidayatulail, M. Yasin, and S. Dyah Astuti, "Photodynamic Inactivation for Phatogenic Bacteria: Adding Chlorophyll and Oxygen," 2018.

[3] Z. Oruba, P. Labuz, W. Macyk, and M. Chomyszyn-Gajewska, "Antimicrobial photodynamic therapy-A discovery originating from the pre-antibiotic era in a novel periodontal therapy," Photodiagnosis and Photodynamic Therapy. 2015.

[4] S. Siswanto, D. A. Prasetya, N. Rachman, and B. F. Hidayatulail, "Pengendali Robot Beroda Berbasis Sensor Telemetri Voice Pattern Recognition," JASIEK (Jurnal Apl. Sains, Informasi, Elektron. dan Komputer), 2019.

[5] P. N. Prasad, "Nanotechnology for Biophotonics: Bionanophotonics," in Introduction to Biophotonics, 2004.

[6] I. Mujahidin, S. H. Pramono, and A. Muslim, "5.5 Ghz Directional Antenna with 90 Degree Phase 
Difference Output," 2018.

[7] N. S. Anderson, D. A. Norman, and S. W. Draper, "User Centered System Design: New Perspectives on Human-Computer Interaction," Am. J. Psychol., 2006.

[8] A. V. Kachynski et al., "Photodynamic therapy by in situ nonlinear photon conversion," Nat. Photonics, 2014.

[9] M. T. Prakarsa, D. Wahyuni, N. Rachman, and I. Mujahidin, "Optimasi Sistem Komunikasi Dari HT Dengan HP Dalam Pelaksanaan Tugas Operasi Tni Ad Menggunakan Metode DTMF," JASIEK (Jurnal Apl. Sains, Informasi, Elektron. dan Komputer), 2019.

[10] T. Maisch, "Anti-microbial photodynamic therapy: Useful in the future?," Lasers in Medical Science. 2007.

[11] I. C. J. Zanin, R. B. Gonçalves, A. B. Junior, C. K. Hope, and J. Pratten, "Susceptibility of Streptococcus mutans biofilms to photodynamic therapy: An in vitro study," J. Antimicrob. Chemother., 2005.

[12] L. Brancaleon and H. Moseley, "Laser and nonlaser light sources for photodynamic therapy," Lasers Med. Sci., 2002.

[13] C. M. Pitsillides, E. K. Joe, X. Wei, R. R. Anderson, and C. P. Lin, "Selective cell targeting with light-absorbing microparticles and nanoparticles," Biophys. J., 2003.

[14] H. S. Qian, H. C. Guo, P. C. L. Ho, R. Mahendran, and Y. Zhang, "Mesoporous-silica-coated upconversion fluorescent nanoparticles for photodynamic therapy," Small, 2009. 